\title{
Three habits of successful policy entrepreneurs
}

Paul Cairney, Professor of Politics and Public Policy, University of Stirling, p.a.cairney@stir.ac.uk (Final version, 31 January 2017)

\begin{abstract}
Kingdon's multiple streams approach is popular because its metaphor and flexible concepts can be applied empirically in most contexts. However, this feature is also its weakness. Most scholars apply MSA superficially, without describing its metaphor's meaning or connecting concepts to empirical results. This article solves this problem by producing one MSA narrative from a diverse collection of empirical studies. Our hero is the "policy entrepreneur' who knows that the pursuit of ambitious aims such as 'evidence-based policymaking' requires framing a problem, having a solution ready, and exploiting the motive and opportunity of policymakers to select it.
\end{abstract}

Keywords: agenda setting - policy entrepreneurs - multiple streams approach - policymaker psychology - policy cycle - evidence-based policymaking

This is a post-peer-review, pre-copy edited version of an article published in Policy and Politics special issue, Practical Lessons from Policy Theories (proposed and edited by Chris Weible and Paul Cairney). The definitive publisher-authenticated version, Cairney P (2018) Three habits of successful policy entrepreneurs, Policy and Politics, 46 (2), pp. 199-215, is available online at: https://doi.org/10.1332/030557318X15230056771696 


\section{Introduction: how to improve the multiple streams narrative}

The multiple streams approach (MSA) is one of policy scholarship's biggest successes. Kingdon's (1984) study is one the highest cited books in policy studies, there is a thriving programme of empirical application and theoretical refinement, its lessons are applied regularly in interdisciplinary studies, and it is relatively well known and enjoyed by practitioners and students (Herweg et al, 2015; 2017; Zahariadis, 2007; 2014; Jones et al, 2016).

Yet, its success is built on shaky foundations because its alleged strength - its flexible metaphor of streams and windows of opportunity - is actually its weakness. Most scholars describe MSA superficially, fail to articulate the meaning of its metaphor, do not engage with state of the art developments, and struggle to apply its concepts systematically to empirical research (Jones et al, 2016). These limitations create an acute scientific problem: most scholars apply MSA without connecting it to a coherent research agenda. Consequently, it is difficult to produce new knowledge systematically or describe with confidence the accumulated wisdom of MSA. As the special issue on 'Practical lessons from policy theories' shows, this problem is a feature of many policy theories which have expanded far beyond their original intentions (Weible and Cairney, 2018).

There have been some recent attempts to solve this problem by encouraging conceptual clarity via hypothesis production and testing (Cairney and Jones, 2016; Cairney and Zahariadis, 2016; Herweg et al, 2015). However, this solution only appeals to a niche audience of MSA scholars. Most readers and users of MSA draw on Kingdon's (1984) classic metaphor without taking their research to the next level by engaging with over 30 years of subsequent research and theoretical refinement. Kingdon's study of US federal politics in the 1980s can only take us so far. Therefore, we need a more profound solution that draws the attention of all MSA users to state of the art research, its applications, refinements, and contemporary implications. Its success will provide benefits to everyone, from the expert scholar to the new student.

I solve this problem in three ways. First, I turn lessons from individual studies and systematic and qualitative reviews of the literature into a coherent MSA narrative. If successful, this narrative will become the primary reference point for policy scholars seeking to conduct new empirical research and explain MSA to new audiences such as students, practitioners, and scholars from other disciplines. It will therefore serve as a valuable heuristic: if they have not read this article, they have not done their homework.

Second, I apply this narrative to a profoundly important topic for interdisciplinary scholars and policymakers - the politics of 'evidence based policymaking' - to show how to make the MSA story as memorable, widely understood, and correctly applied as possible. The result is a theory whose flexibility, undoubted popularity, and wide application does not come at the expense of conceptual clarity.

Third, I focus primarily on 'policy entrepreneurs' as the heroes of the MSA story. Policymakers have to ignore most policy problems and most ways to understand and solve them. When their attention lurches to a problem, it is too late to produce a new solution. Their motive to select any solution is fleeting, during a brief 'window of opportunity'. So, I structure the article 
around the three strategies that effective policy entrepreneurs combine to adapt to these limitations in their complex and unpredictable environment:

1. telling a good story to grab the audience's interest,

2. producing feasible solutions in anticipation of attention to problems, and

3. adapting their strategy to the specific nature of each 'window'. In large systems, they are like surfers waiting for the 'big wave', but in small subsystems they can be like Poseidon moving the 'streams'.

Therefore, a focus on the MSA story and the strategies of entrepreneurs helps consolidate the research agenda for specialist policy scholars and explain real world policymaking to anyone hitherto attached to romantic stories of 'evidence based policymaking' in which we expect policymakers to produce 'rational' decisions in a policy cycle with predictable, linear stages.

\section{How does the multiple streams story begin?}

The MSA story begins as an antidote to the biggest work of fiction in policy studies: rational policymaking during a policy cycle. In an ideal-type world, policymaking would not seem so counterintuitive. 'Comprehensively rational' policymakers would combine their values with evidence to define policy problems and their aims, 'neutral' bureaucracies would produce multiple possible solutions consistent with those aims, and policymakers would select the 'best' or most 'evidence based' solution. This act would set in motion a cycle of stages including legitimation, implementation, evaluation, and the choice to maintain or change policy. The policy process would be predictable, and all actors would know how to engage with policymakers to translate their evidence into policy. We describe this fictional story of 'comprehensive rationality' and the 'policy cycle' as an ideal-type to compare with more realistic stories of complexity and unpredictable policymaking (Cairney, 2016: 16-9).

In the real world, policymaking often seems counterintuitive. There is too much information, and policymakers have to ignore most policy problems and most ways to understand and try to solve them. They use 'rational' and 'irrational' cognitive short cuts to help them pay attention to a manageable number of issues, and address policy problems without fully understanding them (Cairney and Kwiatkowski, 2017). When their attention lurches to a policy problem, it is too late to produce a new solution that is technically feasible and acceptable to policymakers. Their willingness and ability to select a policy solution is fleeting, during a brief 'window of opportunity' in which all key factors - heightened attention to a problem, an available and feasible solution, and the motive to select it - must come together at the same time, or the opportunity is lost (Kingdon, 1984).

Our heroes are the successful 'policy entrepreneurs' who do not get discouraged by this more confusing story. The policy literature describes 'policy entrepreneur' in many ways (Beeson and Stone, 2013; Mintrom and Vergari, 1996: 431; Mintrom and Norman, 2009; Bakir et al, 2017; Jones, 1994: 196; John, 1999: 45; Christopoulos and Ingold, 2015; Laffan, 1997; Roberts and King, 1991). However, as described by our chosen narrator (Kingdon, 1984: 165-6), they are the agents for policy change who possess the knowledge, power, tenacity, and luck to be able to exploit key opportunities. Entrepreneurs invest their time wisely for future reward, and 
possess key skills that help them adapt particularly well to their environments (Cairney, 2012: 272).

Entrepreneurs use three strategies to maximise their impact in crowded, complex, and often unpredictable policy environments. First, they know that agenda setting is about exercising power to generate attention for some issues over others, and establishing one way of thinking about problems at the expense of the others. To that end, entrepreneurs identify how to manipulate or reinforce the cognitive biases of influential policymakers. For example, they tell simple and persuasive stories combining facts with values and emotional appeals, engaging in coalitions and networks to establish trust in the messenger, and investing for the long term to learn the language of policy in key venues.

Second, they know that timing matters. There is not enough time to find a new policy solution during heightened attention to a policy problem. Instead, they develop technically and politically feasible solutions - in other words, they could work as intended and be acceptable to enough people in policy networks - and wait for the right time to present them to policymakers during a 'window of opportunity'.

Third, they know how to adapt to their environment to exploit, or help create, 'windows of opportunity' for action, in which policymakers have some motive to select a policy solution during heightened attention to a problem. The power of entrepreneurs can change markedly according to the scale of the policymaking environment. For Kingdon (1984), policy entrepreneurs in the US federal environment were 'surfers waiting for the big wave', suggesting that the environment is more important to explanation than the skills of individual actors. More recently, there have been hundreds of applications of MSA across the globe, generating new insights and practical implications (Jones et al, 2016). In particular, studies of subnational government, or policymaking in smaller countries or regions, suggest that entrepreneurs can - under particular conditions - be more influential than Kingdon (1984) suggested.

MSA tells a persuasive story about the role of timing and fleeting opportunity in politics. The attention of policymakers lurches frequently, but it is rare for them to possess a fully 'evolved' policy solution before their attention lurches elsewhere. Consequently, attention can rise and fall without producing major policy change.

MSA contrasts with the story of a linear policy cycle in which each stage appears in chronological order, and attention to the nature of a problem sets in motion the production and delivery of a solution. Instead, three key factors - problem definition, policy solution, and politics (motive and opportunity) - are separate 'streams' which rarely 'couple' during a window of opportunity.

If described - rather confusingly - as water, the multiple streams metaphor suggests that, when streams come together, they are hard to separate. Or, if we describe the need for the 'stars to align' we overemphasise the role of serendipity and events completely out of the control of actors (in this scenario, 'no one can rewrite the stars'). Instead, a 'window of opportunity' is best described as akin to a space launch in which policymakers will abort the mission unless every relevant factor is just right. Some factors are not in the gift of humans (such as the 
environmental conditions), but others are (such as the choices we make on technology, resources, and the rules governing lift-off). This metaphor suggests that the 'coupling' of streams is not inevitable, but entrepreneurs can help make things happen because they know the importance of framing problems to generate attention, to have a solution ready, and to help create and exploit infrequent opportunities to act.

Such strategies may be known to policy scientists, but scholars do not tell the same story. We should not underestimate the vulnerability of MSA to poor scientific practice if we do not tell its story consistently and accumulate knowledge systematically. Further, we should not underestimate the profound novelty and value of these insights to the researchers from many disciplines and professions, who are interested in the relationship between evidence and policy, but are more familiar with romantic stories of 'evidence based policymaking' in which we should expect policymakers to produce 'rational' decisions in a policy cycle with predictable, linear stages. MSA provides an equally memorable and attractive story with more value to scholars and practitioners. It provides three ways to be more effective in politics and less disappointed in the gulf between real world and fantasy policymaking.

\section{Entrepreneurs know why it is important to tell a good story about a policy problem}

It is a truism in policy studies that 'the evidence' does not speak for itself. Someone needs to speak up for a policy problem in a way that sparks the attention and concern of their audience. This act does not involve providing more and more evidence, based on the misguided assumption that it will takes us closer to the type of 'comprehensive rationality' associated with 'evidence based policymaking' (EBPM) (Cairney, 2016: 15-18; Douglas, 2009). Rather, early post-war studies identified the implications of 'bounded rationality' when, for example, policymakers used 'rules of thumb' to limit their analysis and trial and error strategies to produce 'good enough' decisions (Simon, 1976: xxviii; Lindblom, 1959: 88). Then, modern theories took forward psychological insights (Kahneman, 2012; Haidt, 2001) to identify two drivers of agenda setting dynamics, whose implications are identified in table 1 .

First, policymakers can only pay attention to a tiny proportion of their responsibilities, so they ignore most evidence and promote very few issues to the top of their agenda (Baumgartner and Jones, 1993). They can only pay attention to one of many possible ways to understand and seek to solve problems, and this attention relates more to the beliefs of policymakers, and persuasion strategies of influencers, than the size of the problem or evidence base for its solution (Majone, 1989: 24; Dearing and Rogers, 1996). Second, policymakers draw on emotion, moral reasoning, gut instinct, and habit as shortcuts to gathering information, to understand complex policy problems in simple ways (Lewis, 2013; Cairney and Kwiatkowski, 2017; Lodge and Wegrich, 2016). In other words, they pay attention to things they care about, or are already familiar with.

Consequently, entrepreneurs know not to bombard policymakers with more and more information as a way to generate attention, since it may have the opposite effect. Rather, they adapt to the ways in which policymakers combine 'rational' and 'irrational' thinking to sift large amounts of potentially relevant information. They perform the role of 'problem broker', to influence how policymakers understand a policy problem, and 'knowledge broker', to supply the concise evidence that is most relevant to this understanding (Knaggård, 2015: 453). 
Agenda setters build on the issues 'already in the back of people's minds' (Kingdon, 1984: 103). As the wider public policy literature suggests, they combine evidence and emotional appeals (True et al, 2007), tell simple stories with heroes and morals (McBeth et al, 2014), romanticise their own cause while demonizing their opponents (Sabatier et al, 1987), and/or exploit stereotypes of social groups to describe why governments should only give resources to the 'deserving' (Schneider and Ingram, 1993; 1997; 2005). These ways to exercise power with reference to the beliefs and psychology of policymakers - can be as important as the material resources of actors (Kingdon, 1984: 133; 131).

Table 1 Strategies for the 'problem stream': how to influence the policy agenda

\begin{tabular}{|l|l|}
\hline Insight & Implication for strategy \\
\hline $\begin{array}{l}\text { Few problems reach the top of the agenda, } \\
\text { and attention to problems is not dependent on } \\
\text { the evidence of their size }\end{array}$ & $\begin{array}{l}\text { Find ways to draw attention to problems by } \\
\text { focusing on the beliefs of your audience } \\
\text { more than your assessment of the evidence }\end{array}$ \\
\hline $\begin{array}{l}\text { Policymakers use 'rational' and 'irrational' } \\
\text { ways to process a lot of information in a short } \\
\text { space of time }\end{array}$ & $\begin{array}{l}\text { Adapt to the cognitive biases of influential } \\
\text { policymakers, and frame policy solutions as } \\
\text { consistent with dominant ways to understand } \\
\text { problems }\end{array}$ \\
\hline $\begin{array}{l}\text { There are many ways to frame any policy } \\
\text { problem, and evidence often plays a limited } \\
\text { role in problem definition }\end{array}$ & $\begin{array}{l}\text { Combine evidence with framing strategies, } \\
\text { persuasion, and storytelling }\end{array}$ \\
\hline $\begin{array}{l}\text { Limited time forces people to make choices } \\
\text { before their preferences are clear }\end{array}$ & $\begin{array}{l}\text { Adapt to 'rational' and 'irrational' ways in } \\
\text { which policymakers short-cut decisions }\end{array}$ \\
\hline $\begin{array}{l}\text { Policymakers seek to reduce ambiguity as } \\
\text { much as uncertainty }\end{array}$ & $\begin{array}{l}\text { If you simply bombard policymakers with } \\
\text { evidence, they will have little reason to read } \\
\text { it. If you win the 'framing battle', } \\
\text { policymakers will demand evidence on your } \\
\text { problem and solution }\end{array}$ \\
\hline
\end{tabular}

Source: adapted from Cairney and Kwitakowski (2017)

Entrepreneurs recognise the key distinction between the exercise of power to reduce ambiguity and the production of evidence to reduce uncertainty (Zahariadis, 2007: 66; Baumgartner and Jones, 1993: 31; Majone, 1989; Cairney, 2012a: 234). Uncertainty describes a lack of knowledge. Scientists often focus on producing more high quality evidence to reduce uncertainty, using evidence to measure the size of a known problem and the effectiveness of a relevant solution (Cairney et al, 2016; Cairney and Oliver, 2017).

More importantly, ambiguity describes the ability to support more than one way to understand and describe a policy problem. We reduce ambiguity by choosing one policy 'image'. That choice narrows our analysis and produces the conditions under which we can use evidence to reduce uncertainty. This is not a 'scientific' process, even if actors can use scientific evidence to make their case. Rather, agenda setting - or problem definition - is about 'framing' issues, or drawing the highest attention to one image by accentuating some facts and omitting others, linking problems to deeply held beliefs and values, using simple stories to assign cause and responsibility, exploiting crises or events, selecting the measures that produce the most supportive evidence of a problem, and tailoring these strategies to different audiences (Rochefort and Cobb, 1994: vii; Jones and Baumgartner, 2005: 8; Baumgartner and Jones, 
1993: 107-8; 113; Hogwood, 1987: 30; Stone, 1989: 282-3; 2002: 191; Dearing and Rogers, 1996: 37-9; Birkland, 1997).

For example, tobacco control is often treated as a model for evidence advocates, in which the scientific evidence played a key role in debate at a national and international level (Cairney et al, 2012). Yet, the availability of evidence produced with scientific rigour was only one part of the agenda setting story, in which advocates of tobacco control also learned to: combine the scientific evidence on the harms of smoking, and harms of environmental tobacco smoke, with emotional appeals regarding the harms to children; challenge the frames of their competitors by quantifying the economic costs of smoking; reframe the implications of key values, such as the right to health and clean air over the right to smoke; and, generate a sense of crisis by describing smoking as a 'non-communicable disease' (NCD), 'epidemic', or public health 'crisis' (Baumgartner and Jones, 1993: 114; Cairney and Yamazaki, 2017; Cairney, 2016a: 6772).

\section{Entrepreneurs have a solution ready to chase a problem}

It is a major but temporary achievement to focus policymaker attention on one way of understanding a policy problem. It must be acted upon quickly, before attention shifts elsewhere. Further, since policymakers will not dwell on problems that cannot be solved, $a$ well thought out solution must already exist before a lurch of attention (Kingdon, 1984: 103). So, entrepreneurs respond to the counterintuitive nature of the agenda setting process: politics is about well-established solutions chasing problems, not producing solutions when policymakers identify problems.

In other words, problem definition is only one part of the puzzle; a necessary but insufficient condition for major policy change. Instead of viewing agenda setting as one stage in a linear process in which problem definition is followed by formulation, legitimation, and implementation, MSA draws on the 'garbage can model' of choice in which policymaking organizations are, 'collections of choices looking for problems, issues and feelings looking for decision situations in which they might be aired, solutions looking for issues to which they might be an answer, and decision makers looking for work' (Cohen et al., 1972: 1). This is 'organized anarchy' in which 'stages' should be viewed instead as 'relatively independent streams' which come together in a mess of activity: some actors articulate a poor or contested understanding of problems in relation to their vague aims, some have their preferred solutions and are looking to attach them to problems, and policymakers have unclear motives when selecting them (1972: 16).

Kingdon (1984) extended this focus on multiple streams to the US federal arena, to describe the conditions under which major policy change would take place. In particular, when policymaker attention lurches to a policy problem, a technically and politically feasible solution must already be available to address the problem defined by policymakers. Further, while attention lurches quickly from issue to issue, viable solutions involving major policy change take years or decades to develop. Kingdon describes ideas in a 'policy primeval soup', evolving or 'softening' as they are proposed by one actor then reconsidered and modified by a large number of participants (who may also have to be 'softened up' to new ideas). To deal with this disconnect between lurching attention and slow policy development, they try to develop widely-accepted solutions in anticipation of future problems, then find the right time to exploit or encourage attention to a relevant problem (1984: 181). 
This insight should not be understated, and the implications laid out in table 2 can have a profound impact on people seeking policy influence. In particular, for people new to politics, who possess the reasonable expectation that we generate solutions after we identify problems, it will seem counterintuitive that there is not enough time to do so. Yet, attention lurches quickly from issue to issue, and the motive to act is temporary, so "When the time for action arrives, when the policy window ... opens, it is too late to develop a new proposal from scratch. It must have already gone through this process of consideration, floating up, discussion, revision and trying out again' (1984: 149). Therefore, 'advocates lie in wait in and around government with their solutions at hand, waiting for problems to float by to which they can attach their solutions, waiting for a development in the political stream they can use to their advantage' (Kingdon 1984: 165-6).

Table 2 Strategies for the policy stream: how to develop and gain support for policy solutions

\begin{tabular}{|l|l|}
\hline Insight & Implication \\
\hline $\begin{array}{l}\text { There is no linear policy cycle in which } \\
\text { policymakers identify problems, formulate } \\
\text { solutions, and make a choice }\end{array}$ & $\begin{array}{l}\text { Generate technically and politically feasible } \\
\text { policy solutions and seek opportunities to } \\
\text { sell them during heightened attention }\end{array}$ \\
\hline $\begin{array}{l}\text { Solutions take time to 'soften' to become } \\
\text { accepted within policy networks }\end{array}$ & $\begin{array}{l}\text { Form coalitions with allies, and engage in } \\
\text { networks, to identify how to modify and } \\
\text { generate support for policy solutions }\end{array}$ \\
\hline
\end{tabular}

Source: adapted from Cairney and Zahariadis (2016) and Mintrom and Norman (2009).

MSA therefore helps clarify the role of 'timing' and idioms such as 'being in the right place at the right time' in policymaking. The absence of good timing is listed frequently as a major barrier to the use of scientific evidence in policy, prompting scholars to recognise the need for good networks to help spot opportunities, while recognising the 'serendipitous nature of the policy process' (Oliver et al, 2014a: 4). This emphasis on timing as serendipity is also reinforced in some studies of the policy implications of MSA (Avery, 2004; Howie, 2009; Pralle, 2009). Yet, entrepreneurs also help create windows of opportunity and have solutions ready when the time is right.

Just how long it takes to 'soften' a solution and wait for the right opportunity is unclear, but note the use of different metaphors. Smith (2014) describes the chameleon-like nature of ideas, suggesting they can potentially change quickly to adapt to a new environment. However, Kingdon (1984) uses a 'Darwinian' evolutionary metaphor, which suggests 'the slow progress of an idea towards acceptability' within policy networks, which might take decades (Cairney, 2013: 281). In such cases, evidence advocates should prepare for the long haul and expect limited short term influence (Boswell and Smith, 2017). Indeed, even if they expect a new government to arrive with new ideas, or a new level of receptivity to solutions, they still need to be ready with a well worked out solution.

\section{Entrepreneurs know when to 'surf the waves' or try to move the sea}

To produce major policy change, policymakers have to possess the motive to pay attention to a problem and adopt the proposed solution. This motive is fleeting, during a 'window of opportunity'. Potential causes of a shift in receptivity to a policy solution include: 'Swings of national mood, vagaries of public opinion, election results, changes of administration ... and interest group pressure campaigns' (Kingdon, 1984: 19). To return to the metaphor of a timely space launch out of the control of any single actor, our attention should shift to the importance 
of a 'policy environment'. In most modern policy theories, this 'environmental' relates to the attitudes of many potentially influential audiences (actors at multiple levels of government or in key venues), the rules and norms of information gathering and behaviour in key venues, the supportive coalitions and networks, and the most relevant socioeconomic trends and key events (Heikkila and Cairney, 2017; Cairney and Weible, 2017)

In Kingdon's original study, Darwinian and environmental metaphors describe the vast scale of US federal-level politics and policymaking, in which it is difficult to imagine that one entrepreneur could do anything but adapt to rather than shape their environment. Modern MSA studies help shift that image somewhat. Jones et al (2016) identify 311 MSA applications published from 2000-2014, of which 132 are to the US, 205 to European countries or the EU, and 140 studies are outside both (many compare systems, so the number is above 311 ). The MSA has inspired applications in at least 65 countries and over 100 applications to subnational policymaking. This breadth of focus is also reflected in Zahariadis' (2014) 'illustrative list' of 41 texts, used by Cairney and Jones (2016: 44) to provide a more qualitative analysis of the modern insights generated by MSA studies. In it, there are national (20), subnational (13), and international (8) applications (including the EU and UN); and, while the US and Europe account for most, there are enough non-traditional applications - in countries such as China and Burkina Faso - to explore the extent to which practical lessons from the federal US extend to other countries or levels of government (see also Rawat and Morris, 2016).

Using these new studies, we can say that the insights from tables 1 and 2 have a 'universal' quality, in which they can be applied to any time or place (Cairney and Jones, 2016: 39), but their implications can change markedly in different applications.

To demonstrate, first consider key aspects of the context in which Kingdon generated his original analysis, and the new questions that arise if we shift our focus to other case studies:

- Few problems reach the top of the agenda because US federal policy can apply to almost all aspects of social and political life. What happens when some venues only consider a small number of issues?

- There are many ways to define issues, and the US 'macropolitical' level resembles an 'issue network' in which there are many actors competing to define issues (Baumgartner and Jones, 1993; Heclo, 1978). What happens in less competitive arenas where some definitions dominate debate for years or decades?

- Problems, policies, and politics are separate 'streams' partly as a function of the size of the US system and limits to key roles, such as when the President sets agendas but other actors generate solutions. What happens when key actors can become influential in more than one stream?

- The 'policy primeval soup' metaphor works for a US political system in which solutions take time to 'soften' and a piece of legislation may only gain traction when a large number of actors in a policy networks have engaged with and modified the original policy proposal. What happens when this initial process happens externally, such as in international organisations or networks or in other countries? The role of 'policy transfer' is discussed more in non-US or subnational US studies (Dolowitz and Marsh, 1996). 
- MSA began as a study of a two-party political system with a division of powers between executive, legislative, and judicial branches. What happens in parliamentary systems in which the role of the executive and multi-party competition is more important (Herweg et al, 2015)?

Generally, outside of Kingdon's original study, there is often more scope for entrepreneurs to influence their environment or generate a wider range of strategies. Although the literature on this specific topic is patchy, and it is often difficult to compare cases (Jones et al, 2016; Cairney and Jones, 2016), key studies provide the following preliminary insights (table 3).

Table 3 Strategies for the 'politics stream' and to exploit 'windows of opportunity'

\begin{tabular}{|l|l|}
\hline Insight & Implication for strategy \\
\hline $\begin{array}{l}\text { Actors dissatisfied with progress in one } \\
\text { policymaking venue can seek more } \\
\text { sympathetic audiences elsewhere }\end{array}$ & $\begin{array}{l}\text { Engage in 'venue shopping' to encourage } \\
\text { 'venue shift' and reduce the need to 'soften' } \\
\text { policy solutions }\end{array}$ \\
\hline $\begin{array}{l}\text { Policymakers often import policy solutions } \\
\text { from other political systems, which may } \\
\text { reduce the need to 'soften' solutions in } \\
\text { domestic networks }\end{array}$ & $\begin{array}{l}\text { Engage in multi-level policy networks to } \\
\text { seek opportunities to import 'pre-softened' } \\
\text { policy solutions }\end{array}$ \\
\hline $\begin{array}{l}\text { Policy entrepreneurs can be more effective at } \\
\text { a smaller scale of government }\end{array}$ & $\begin{array}{l}\text { Recognise your potential role, as a surfer on } \\
\text { the waves, or Poseidon moving them }\end{array}$ \\
\hline $\begin{array}{l}\text { In some systems, or during crises, the usual } \\
\text { rules of MSA do not apply. Some MSA } \\
\text { insights are not 'universal' }\end{array}$ & $\begin{array}{l}\text { Do your homework on specific political } \\
\text { systems, to understand the idiosyncrasies of } \\
\text { the policy environment }\end{array}$ \\
\hline $\begin{array}{l}\text { The most frequent or predictable policy } \\
\text { windows could be elections }\end{array}$ & $\begin{array}{l}\text { Do not simply equate a 'window of } \\
\text { opportunity' with unpredictable serendipity. } \\
\text { Link problems to election debates, and seek } \\
\text { solutions demonstrably popular with key } \\
\text { parts of the public }\end{array}$ \\
\hline $\begin{array}{l}\text { Policymakers often select vague solutions to } \\
\text { ill-defined problems during a policy window. }\end{array}$ & $\begin{array}{l}\text { Do not put your faith in the policy cycle to } \\
\text { ensure that broad intentions translate into the } \\
\text { delivery of specific solutions }\end{array}$ \\
\hline
\end{tabular}

Source: adapted from Cairney and Jones (2016)

Venue shop and frame issues to promote venue shift

MSA suggests that policy solutions only become feasible when they are acceptable to enough actors in key venues such as policymaking institutions or networks (Kingdon refers broadly to the 'policy community', but beware the potential for terminological confusion - Cairney, 2012: $235 ; 179)$. Punctuated equilibrium theory modifies this expectation by focusing on the role of venue shopping, when actors are dissatisfied with progress in one venue and seek more sympathetic audiences elsewhere (Baumgartner and Jones, 1993: 35-7). If successful, they short-cut the 'softening' process in venues where audiences are more sympathetic to policy change (1993: 32-3; Cairney, 2013: 282).

Some modern MSA applications, particularly in the EU, use this insight to show that competition to reduce ambiguity relates simultaneously to problem definition and defining the 
most appropriate venue to address it (Ackrill and Kay, 2011, Sarmiento-Mirwaldt, 2013). In other words, the main definition of a policy problem can determine the venue held responsible for solving it: if tobacco is primarily a public health epidemic, rely on a health department; if it is a valuable commodity for trade and taxation, rely on trade and treasury departments (Cairney et al, 2012).

However, we should be careful not to overstate the frequency and potential of such shifts, particularly if we assume that actors in each venue can be possessive about policy issues. Successful venue shift involves a level of energy not available to many actors. For example, Cairney $(2006 ; 2007 b ; 2009)$ initially described the reframing of a ban on smoking in public places - as a public health issue (a Scottish Parliament responsibility) rather than health and safety (Westminster) - as one of potentially many venue shifts, only to fail to see another example in the next 10 years.

\section{Learn how to short-cut the softening process by importing pre-softened solutions}

Non-US and subnational US studies identify the role of policy transfer and diffusion as a relatively quick way to shortcut the softening process. Policy transfer can be a response to 'bounded rationality': policymakers and influencers use external examples of successful policy innovation to set the agenda and present already-solved policy problems. Or, in some cases, federal, supranational bodies, and international organisations (or powerful countries like the US) put pressure on others to import policy solutions (Berry and Berry, 2014; Dolowitz and Marsh, 1996; Rose, 2005; Cairney, 2012: 108). Modern MSA studies identify many examples of the role of policy transfer in short-cutting the 'softening' process associated with Kingdon's original study (Bache, 2012; Bache \& Reardon, 2013; Cairney, 2009; Liu, Lindquist, Vedlitz, \& Vincent, 2011; McLendon, 2003; Zahariadis, 2004).

Again, we should not overestimate the potential effect of policy transfer. External policymakers provide the source of new solutions, but MSA helps explain the conditions under which they would be accepted during a 'policy transfer window' (Cairney, 2012: 269-71). For example, most countries agreed to the same package of policy solutions in the WHO Framework Convention on Tobacco Control, but very few have the environments conducive to the adoption of those policy instruments during subsequent policy windows. Consequently, the implementation of imported policy solutions is highly uneven (Cairney and Yamazaki, 2017) and, in some countries, almost non-existent (Mamudu et al, 2015).

\section{Identify the conditions under which entrepreneurs emulate Poseidon}

Subnational MSA studies suggest that policy entrepreneurs can be more effective at 'a smaller and/or more local scale of government' (Cairney and Jones, 2016: 46). Henstra (2010), Oborn et al (2011), and Dudley (2013) identify examples of scales small enough for an entrepreneur to influence all three streams successfully: $\$ 100 \mathrm{k}$ funding for a Canadian municipal emergency management policy, healthcare reform inside London, and the London mayor as framer and audience for a road congestion charge. Robinson and Eller (2010) also find that, in Texas schools policy, the streams are not separate in the way Kingdon describes, since key actors are involved in all three. Each example raises the possibility that the coupling of streams by entrepreneurs is more straightforward in smaller and more manageable issues (even if their analytical separation began as a way to explain 'organised anarchy' in a small, single organisation - Cohen et al, 1972). 
Identify the times when the usual rules of MSA seem not to apply

Hall (1993) identifies the rare occasions in one political system (UK) in which the rules of policy softening and feasibility no longer apply: during crisis leading to paradigm change, the old ideas and their proponents are no longer relevant (albeit, Hall was not engaging with MSA - see Cairney, 2013: 283). Zhu's (2008) MSA case study of China adds the possibility that, in some political systems with very different procedures to the US, the rules of softening may also not apply. Zhu identifies the role of technical infeasibility: actors can propose a politically acceptable solution that cannot be dealt with routinely by the governing bureaucracy, prompting high external and government attention, and potentially major policy change. The case study implication is so different to Kingdon's that it reminds us to question the 'universal' applicability of any practical solution generated by MSA.

\section{Be realistic about the frequency and cause of windows of opportunity}

Howlett's (1998) quantitative analysis of Canadian politics suggests that elections represent the most frequent source of a window of opportunity for policy change. He provides a way to challenge the idea of a serendipitous aligning of the stars which can happen at any moment, suggesting that planning for an election may be more sensible than for a random event. Herweg et al (2015: 437) identify more specific drivers for policymakers: to pay attention to problems, including when it 'puts the policy makers' re-election at risk'; and, become receptive to solutions, including when the solution is popular among the public and key interest groups, or when the governing political party is seen as competent in this field and has made an ideological commitment to a particular approach. Such statements remind us of the important role of party competition in salient issues (since policy studies often downplay such dynamics).

Note the difference between a window of opportunity for a broad idea or specific solution Cairney et al (2017: 118) suggest that, in the case of 'prevention' policy in the UK, policymakers 'paid attention to an ill-defined problem and produced a solution which often proves to be too vague to operationalize in a simple way'. There was high support and enthusiasm to prompt a shift from reactive public services towards earlier intervention in people's lives, but limited discussion of the specific ways in which they would deliver welldefined solutions. Such experiences remind us of the absence of a policy cycle with linear and ordered stages. If a cycle existed, this initial resolution of a problem at the agenda setting stage would be followed by more detailed solution production, formulation, and implementation. If not, an idea's time may come and go without any meaningful resolution, beyond this broad commitment to do something.

\section{Conclusion}

It is important to tell the MSA story well. A concise and coherent theoretical story aids metaphorical and conceptual clarity, encourages a coherent research programme, and allows all relevant audiences - from expert policy scholars to scientists and practitioners in other fields and new students - to understand and communicate its insights in similar ways.

To that end, I told the well-established story of MSA in relation to new debates on 'evidence based policymaking'. In that context, MSA provides insights which might seem counterintuitive to actors less familiar with policy theories and still hoping for EBPM. Modern EBPM debates seem to be built on renewed hopes for comprehensive rationality and a linear policy cycle. In contrast, I describe policymaking in the real world by identifying the three strategies used by successful policy entrepreneurs. 
First, entrepreneurs tell a persuasive story to frame a policy problem. Few problems reach the top of the agenda, and attention to problems is not dependent on the evidence of their size. Instead, policymakers face too much information, use 'rational' and 'irrational' ways to process a lot of information, and make choices in a short space of time without being fully aware of their preferences. Policymakers seek to reduce ambiguity, by focusing on a simple definition of a complex problem, and uncertainty, by gathering information relevant to that definition. Entrepreneurs focus on the beliefs of their audience more than their assessment of the evidence. They reinforce the cognitive biases of influential policymakers by combining facts with values and emotional appeals, and by framing policy solutions as consistent with dominant ways to understand problems. If you simply bombard policymakers with evidence, they will have little reason to read it. If you win the 'framing battle', policymakers will demand evidence on your problem and solution.

Second, entrepreneurs make sure that their favoured solution is available before attention lurches to the problem. There is no policy cycle in which policymakers identify problems, formulate solutions, and make a choice in that order. Instead, by the time policymakers pay attention to a problem it is too late to develop a technically and politically feasible solution from scratch. Solutions take time to 'soften' and become accepted within policy networks, and entrepreneurs seek opportunities to sell their solutions during heightened attention, by forming coalitions and engaging in networks to identify receptivity to policy solutions and an opportunity to act.

Third, entrepreneurs exploit a 'window of opportunity' during which policymakers have the willingness and ability to adopt their policy solution. The role of entrepreneurs changes at different scales and in different systems. Further, modern studies highlight a wider range of strategies for entrepreneurs seeking to influence windows of opportunity, including: 'venue shopping' to seek more sympathetic audiences, encourage 'venue shift', and reduce the need to 'soften' policy solutions; engaging in multi-level policy networks to seek opportunities to import 'pre-softened' policy solutions; adapting to the idiosyncrasies of the policy environments in different political systems; as well as the more obvious value of linking problems to election debates and seeking solutions demonstrably popular with key parts of the public.

This story may seem familiar to people who have read Kingdon (1984), but MSA has come a long way since his foundational text was published. We need to incorporate three decades of empirical application and conceptual refinement into a coherent modern MSA story and, while doing so, make sure that the meaning of its attractive metaphor remains clear. Only then can policy scholars be sure that their empirical applications of MSA form part of a far larger narrative of the policy process.

\section{References}

Ackrill, Robert, and Adrian Kay. 2011. 'Multiple Streams in EU Policy-Making: The Case of the 2005 Sugar Reform,' Journal of European Public Policy 18: 72-89

Avery, George. 2004. 'Bioterrorism, Fear, and Public Health Reform: Matching a Policy Solution to the Wrong Window,' Public Administration Review 64: 274-288 
Bache, Ian. 2013. 'Measuring Quality of Life for Public Policy: An Idea whose Time has Come? Agenda-setting Dynamics in the European Union,' Journal of European Public Policy (20): 21-38.

Bache, Ian, and Louise Reardon. 2013. "An Idea Whose Time has Come? Explaining the Rise of Well- Being in British Politics." Political Studies 61 (4): 898-914

Bakir, C. and Jarvis, D. S. L. (2017) 'Contextualising the context in policy entrepreneurship and institutional change', Policy and Society, in press

Baumgartner, F.and Jones, B. $(1993 ; 2009)$ Agendas and Instability in American Politics. $1^{\text {st }}$ and $2^{\text {nd }}$ eds. (Chicago: Chicago University Press)

Beeson, M. and Stone, D. (2013) 'The Changing Fortunes of a Policy Entrepreneur: The Case of Ross Garnaut', Australian Journal of Political Science, 48, 1, 1-14

Berry, F. and Berry, W. (2014) 'Innovation and Diffusion Models in Policy Research' in Sabatier, P. and Weible, C. (eds.) Theories of the Policy Process $3^{\text {rd }}$ edition (Chicago: Westview Press)

Birkland, T. (1997) After Disaster: Agenda Setting, Public Policy, and Focusing Events (Washington, DC: Georgetown University Press)

Boswell, C. and Smith, K. (2017) 'Rethinking policy 'impact': four models of research-policy relations', Palgrave Communications, 3, 44, 1-10 doi:10.1057/s41599-017-0042-z

Cairney, P. (2006) 'Venue Shift Following Devolution: When Reserved Meets Devolved in Scotland', Regional and Federal Studies, 16, 4, 429-45

Cairney, P. (2007b) 'Using Devolution to Set the Agenda? Venue shift and the smoking ban in Scotland', British Journal of Politics and International Relations, 9, 1, 73-89

Cairney, P. (2009) 'The Role of Ideas in Policy Transfer: The Case of UK Smoking Bans since Devolution,' Journal of European Public Policy 16: 471-488

Cairney, P. (2012) Understanding Public Policy (Basingstoke: Palgrave)

Cairney, P. (2013) 'What is Evolutionary Theory and How Does it Inform Policy Studies?' Policy and Politics, 41, 2, 279-98

Cairney, P. (2016) The Politics of Evidence Based Policy Making (London: Palgrave Springer)

Cairney, P. and Jones, M. (2016) 'Kingdon's Multiple Streams Approach: What Is the Empirical Impact of this Universal Theory?' Policy Studies Journal, 44, 1, 37-58

Cairney, P. and Kwiatkowski, R. (2017) 'How to communicate effectively with policymakers: combine insights from psychology and policy studies', Palgrave Communications, 3, 37, doi:10.1057/s41599-017-0046-8

Cairney, P. and Oliver, K. (2017) 'Evidence-based policymaking is not like evidence-based medicine, so how far should you go to bridge the divide between evidence and policy?' Health Research Policy and Systems, 15, 35, https://doi.org/10.1186/s12961-017-0192-x 
Cairney, P., Oliver, K. and Wellstead, A. (2016a) 'To Bridge the Divide between Evidence and Policy: Reduce Ambiguity as Much as Uncertainty', Public Administration Review, 76, 3, 399402 DOI:10.1111/puar.12555

Cairney, P. and Yamazaki, M. (2017) 'A comparison of tobacco policy in the UK and Japan: if the scientific evidence is identical, why is there a major difference in policy?' Journal of Comparative Policy Analysis, https://doi.org/10.1080/13876988.2017.1323439

Cairney, P., Studlar, D. and Mamudu, H. (2012) Global Tobacco Control: Power, Policy, Governance and Transfer (Basingstoke: Palgrave)

Cairney, P. and Weible, C. (2017) 'The New Policy Sciences', Policy Sciences, 50, 4, 619-27,

Cairney, P. and Zahariadis, N. (2016) 'Multiple streams analysis: A flexible metaphor presents an opportunity to operationalize agenda setting processes' in Zahariadis, N. (eds) Handbook of Public Policy Agenda-Setting (Cheltenham: Edward Elgar)

Cairney, P., Harvey, M and St Denny, E. (2017) 'Constitutional Change, Social Investment and Prevention Policy in Scotland' in (ed) Keating, M. A Wealthier, Fairer Scotland (Edinburgh: Edinburgh University Press)

Christopoulos, D. and Ingold, K. (2015) 'Exceptional or just well connected? Political entrepreneurs and brokers in policy making', European Political Science Review, 7, 475-498

Cohen, M., March, J. and Olsen, J. (1972) 'A Garbage Can Model of Organizational Choice', Administrative Science Quarterly, 17, 1, 1-25

Dearing, J.W. and Rogers, E.M. (1996) Agenda Setting (London: Sage)

Dolowitz, D. and Marsh, D. (1996) 'Who Learns What From Whom: A Review of the Policy Transfer Literature', Political Studies, XLIV: 343-57

Douglas, H. (2009) Science, Policy, and the Value-Free Ideal (Pittsburgh: University of Pittsburgh Press)

Dudley, Geoff. 2013. 'Why do Ideas Succeed and Fail over Time? The Role of Narratives in Policy Windows and the Case of the London Congestion Charge,' Journal of European Public Policy 20: 1139-1156

Haidt, J. (2001) “The Emotional Dog and Its Rational Tail: A Social Intuitionist Approach to Moral Judgment," Psychological Review 108, 4, 814-834

Hall P (1993) Policy Paradigms, Social Learning, and the State: The Case of Economic Policymaking in Britain. Comparative Politics 25 (2): 275-296

Heclo, H. (1978) 'Issue Networks and the Executive Establishment', in A. King (ed.) The New American Political System (Washington DC: American Enterprise Institute)

Heikkila, T. and Cairney, P. 2017 'A Comparison of Theories of the Policy Process' in Weible, C. (ed.) Theories of the Policy Process 4th edition (Chicago: Westview Press) 
Henstra, Daniel. 2010. "Explaining Local Policy Choices: A Multiple Streams Analysis of Municipal Emergency Management.” Canadian Public Administration 53 (2): 241-58

Herweg, N., Huß, C. and Zohlnhöfer, R., 2015. Straightening the three streams: Theorising extensions of the multiple streams framework. European Journal of Political Research, 54(3), pp.435-449.

Herweg, N., Zahariadis, N. and Zohlnhöfer, R. (2017) 'The Multiple Streams Framework: Foundations, Refinements, and Empirical Applications' in (ed) Weible, C. and Sabatier, P. Theories of the Policy Process $4^{\text {th }}$ ed. (Chicago: Westview Press)

Hogwood, B. (1987) From Crisis to Complacency (Oxford: Oxford University Press).

Howie, William O. 2009. 'Mandatory Reporting of Medical Errors: Crafting Policy and Integrating it into Practice,' Journal for Nurse Practitioners 5 (9): 649-654.

Howlett, Michael. 1998. 'Predictable and Unpredictable Policy Windows: Institutional and Exogenous Correlates of Canadian Federal Agenda Setting,' Canadian Journal of Political Science 31: 495-524.

John, P. (1999) 'Ideas and Interests; Agendas and Implementation: An Evolutionary Explanation of Policy Change in British Local Government Finance', British Journal of Politics and International Relations, 1, 1: 39-62.

Jones, B. and Baumgartner, F. (2005) The Politics of Attention (Chicago: University of Chicago Press)

Jones, Michael D., Holly L. Peterson, Jonathan J. Pierce, Nicole Herweg, Amiel Bernal, Holly Lamberta Raney, and Nikolaos Zahariadis. 2016. "A River Runs Through It: A Multiple Streams Meta-Review.” Policy Studies Journal 44 (1): 13-36

Jones, B. (1994) Reconceiving Decision-Making in Democratic Politics: Attention, Choice and Public Policy (Chicago, IL: Chicago University Press)

Kahneman, D. (2012) Thinking Fast and Slow (London: Penguin)

Kingdon J (1984; 1995) Agendas, Alternatives and Public Policies $1^{\text {st }}$ and $2^{\text {nd }}$ eds. New York: Harper Collins

Knaggård, A. (2015) 'The Multiple Streams Framework and the problem broker', European Journal of Political Research 54, 3, 450-465

Laffan, B. (1997) 'From policy entrepreneur to policy manager: the challenge facing the European Commission', Journal of European Public Policy, 4, 3, 422-438

Lewis, P. (2013) 'Policy Thinking, Fast and Slow: A Social Intuitionist Perspective on Public Policy Processes', American Political Science Association 2013 Annual Meeting Available at SSRN: http://ssrn.com/abstract=2300479

Lindblom, C. (1959) 'The Science of Muddling Through', Public Administration Review, 19: $79-88$ 
Liu, Xinsheng, Eric Lindquist, Arnold Vedlitz, and Kenneth Vincent. 2010. "Understanding Local Policymaking: Policy Elites' Perceptions of Local Agenda Setting and Alternative Policy Selection.” Policy Studies Journal 38 (1): 69-91.

Lodge, M. and Wegrich, K. (2016) 'The Rationality Paradox of Nudge: Rational Tools of Government in a World of Bounded Rationality', Law \& Policy, 38(3), pp.250-267

Majone, G. (1989) Evidence, Argument and Persuasion in the Policy Process (New Haven: Yale University Press)

Mamudu, H., Cairney, P. and Studlar, D. (2015) 'Global Public Policy: does the new venue for transnational tobacco control challenge the old way of doing things?' Public Administration, $93,4,856-873$

McBeth, M., Jones, M. and Shanahan, E. (2014) 'The Narrative Policy Framework' in Sabatier, P. and Weible, C. (eds.) Theories of the Policy Process $3^{\text {rd }}$ edition (Chicago: Westview Press)

McLendon, Michael K. 2003. 'Setting the Governmental Agenda for State Decentralization of Higher Education,' Journal of Higher Education 74: 479-516

Mintrom, M. and Norman, P. (2009) 'Policy Entrepreneurship and Policy Change', Policy Studies Journal, 37, 4: 649-67.

Mintrom, M. and Vergari, S. (1996) 'Advocacy Coalitions, Policy Entrepreneurs and Policy Change', Policy Studies Journal, 24, 3: 420-34

Nutley, S., Walter, I. and Davies, H. (2007) Using evidence: how research can inform public services (Bristol: The Policy Press)

Oborn, Eivor, Michael Barrett, and Mark Exworthy. 2011. "Policy Entrepreneurship in the Development of Public Sector Strategy: The Case of London Health Reform." Public Administration 89 (2): 325-44

Oliver, K., Innvar, S., Lorenc, T., Woodman, J. and Thomas, J. (2014a) 'A systematic review of barriers to and facilitators of the use of evidence by policymakers' BMC health services research, 14 (1), 2. http://www.biomedcentral.com/1472-6963/14/2

Oliver, K., Lorenc, T., \& Innvær, S. (2014b) 'New directions in evidence-based policy research: a critical analysis of the literature', Health Research Policy and Systems, 12, 34 http://www.biomedcentral.com/content/pdf/1478-4505-12-34.pdf

Parkhurst, J. (2017). The politics of evidence: from evidence based policy to the good governance of evidence. London: Routledge

Pralle, Sarah B. 2009. 'Agenda-Setting and Climate Change,' Environmental Politics 18 (5): 781-799

Rawat, P. and Morris, J. (2016) 'Kingdon's “Streams” Model at Thirty: Still Relevant in the 21st Century?' Politics and Policy, 44, 4, 608-638. 
Roberts, N. and King, P. (1991) 'Policy Entrepreneurs: Their Activity Structure and Function in the Policy Process', Journal of Public Administration Research and Theory, 1, 2, 147-175

Robinson, Scott E., and Warren S. Eller. 2010. 'Testing the Separation of Problems and Solutions in Subnational Policy Systems,' Policy Studies Journal 38 (2): 199-216.

Rochefort, D.A. and Cobb, R.W. (1994) 'Problem Definition: An Emerging Perspective' in D.A. Rochefort and R.W. Cobb (eds) The Politics of Problem Definition (Kansas City, KS: University Press of Kansas).

Rose, R. (2005) Learning From Comparative Public Policy: A Practical Guide (London: Routledge)

Sabatier, P., Hunter, S. and McLaughlin, S. (1987) 'The Devil Shift: Perceptions and Misperceptions of Opponents', The Western Political Quarterly, 40, 3, 449-476

Sarmiento-Mirwaldt, Katja. 2013. 'Can Multiple Streams Predict the Territorial Cohesion Debate in the EU?' European Urban and Regional Studies doi: 10.1177/0969776413481984

Schneider, A. and Ingram, H. (1993) 'Social Construction of Target Populations: Implications for Politics and Policy’, American Political Science Review, 87, 2, 334-347

Schneider, A. and Ingram, H. (1997) Policy Design for Democracy (Kansas: University of Kansas Press)

Schneider, A. and Ingram, H. (eds) (2005) Deserving and Entitled: Social Construction and Public Policy (Albany, NY: State University of New York Press)

Simon, H. (1976) Administrative Behavior $3^{\text {rd }}$ Edition (London: MacMillan)

Smith, K. (2013) Beyond Evidence Based Policy in Public Health: The Interplay of Ideas (Basingstoke: Palgrave Macmillan)

Stone, D. (1989) 'Causal Stories and the Formation of Policy Agendas', Political Science Quarterly, 104: 281-300.

Stone, D. (2002) Policy Paradox: The Art of Political Decision Making (revised ed) (London: Norton).

True, J.L., Jones, B.D. and Baumgartner, F.R. (2007) Punctuated Equilibrium Theory' in (ed.) P. Sabatier Theories of the Policy Process $2^{\text {nd }}$ Edition (Cambridge MA: Westview Press)

Zahariadis, N. (2004) 'European Markets and National Regulation: Conflict and Cooperation in British Competition Policy,' Journal of Public Policy, 24 (1): 49-73.

Zahariadis, N. (2007) 'The Multiple Streams Framework' in (ed) P. Sabatier Theories of the Policy Process (Cambridge MA: Westview)

Zahariadis, N. (2014) 'Ambiguity And Multiple Streams' in Sabatier, P. and Weible, C. (eds.) Theories of the Policy Process $3^{\text {rd }}$ edition 
Zhu, Xufeng. 2008. 'Strategy of Chinese Policy Entrepreneurs in the Third Sector: Challenges of 'Technical Infeasibility',' Policy Sciences 41: 315-334 